\title{
The Importance of Knowledge about the Preschool Curriculum in Terms of Preschool Administrators' Instructional Leadership Practices
}

\author{
Sevilay ŞAHIN \\ Turkey \\ Gülşen SEZER \\ Turkey
}

Received: May 22, 2017 Accepted: June 20, $2017 \quad$ Published: August 1, 2017

doi:10.5296/jse.v7i3.11264 URL: https://doi.org/10.5296/jse.v7i3.11264

\begin{abstract}
The purpose of the present study was to unearth the importance of school administrators' knowledge about thepreschool curriculum in terms of displaying instructional leadership behaviors in the kindergartens and primary schools with preschool classes. The study group in the research consisted of 20 preschool teachers and 10 preschool administrators working in the schools tied to the Ministry of National Education in Kilis province, chosen via the purposeful sampling technique. Interviews were conducted with the participants to collect the data. The data were then content-analyzed. The results revealed that primary school administrators did not have adequate knowledge about the preschool curriculum and could not display instructional leadership behaviors; however, preschool administrators had, comparatively, adequate knowledge about the curriculum and were more successful in terms of displaying instructional leadership behaviors. Drawing on this point, it may be suggested that knowledge about the preschool curriculum is of utmost importance in preschool administrators' instructional leadership practices.
\end{abstract}

Keywords: Instructional leadership, Preschool education, Knowledge on preschool curriculum 


\section{Introduction}

Today, rapid advancements have been experienced in the field of science and technology. The advancements in these fields have enormously influenced societal, economic and cultural life as well as family life. With these changes in the society, it has been seen that parents are not sufficient on their own for their children's education. Particularly, in the 0-6 age period in which cognitive growth is at its highest and the basis of personality development is laid, education provided by the family remains inadequate for children to grow in accordance with their capacities (Katranc1, 2014). At this point, as put by Ada, Küçükali, Akan and Dal (2014), it may not be right to expect children to go to primary school, adapt to the school in a short time and become successful without receiving any education in a professional sense. Furthermore, preschool education is the first venue that children enter in a professional sense, and it reflects on their later academic and social life and development spheres; therefore, as Poyraz and Dere (2006) state, in this period, a planned and programmed preschool education is sine qua non of developing children's basic abilities. As this education is provided at kindergartens, the quality of kindergartens can be revealed through achieving their existential purpose and ensuring efficiency by reaching prescribed goals, which can be possible with effective management. Drawing on this point, an effective preschool management is expected to bring together all of the elements of the school around a vision, operate teaching and learning activities effectively and have knowledge about the preschool curriculum to realize all these things.

Dale (1969) argues that the first and foremost goal and role of the preschool administrators, like other school administrators, is to achieve more than what schools already have, and while playing this role, they are expected to make use of human resources they work with at an optimum and appropriate level and reach their goals by detecting the most valid purposes, tools and learning processes (Özdemir Topaloğlu, 2009). Sağır (2015) suggests that school administrators have the most important role in using human and material resources rationally in accordance with the goals of the organization and that organizational managers are expected to be leaders and direct organizational members towards organizational goals.

Effective schools and administrators who make schools effective have become the most investigated research topics in the field of educational administration. It may be argued that the most critical element in kindergartens' achieving their goals is school administrators, as it is true for all school levels. The fact that school administrators do their job well, that is, achieve the goals of the organization depends on knowing the existential purpose of the organization, the characteristics of the community served, the values, qualities and philosophy of the organization, the content of the organizational tasks, the environment and materials required to carry out the tasks and identifying the presence of the organization.

When the organization of the Ministry of National Education (MoNE) is examined, it can be seen that all of the preschool education institutions tied to the MoNE are governed through the same regulation. Preschool education in Turkey is mainly via provided preschool classes opened within primary schools and independent kindergartens. Almost all of the school 
administrators who are responsible for preschool classes are the ones educated in different areas from preschool education (Ural \& Ramazan, 2007).

Özdemir Topaloğlu (2009) proposes that the management of preschools and of the state schools, in particular,is left to the decisions and priorities of school administrators who are responsible for primary and middle schools. These institutions are deprived of separate buildings and run with inadequate materials far from meeting the needs of preschool students. One of the most apparent challenges in front of these organizations is the lack of administrators who are educated on preschool education and only responsible for kindergartens, and an initiative about the training of school administrators has been included neither in development plans nor in the National Education Councils. Therefore, a "preschool administrator training process" needs to be urgently launched in order to pave the way for developments in preschool education.

A specific education is required for preschool teachers depending on the differences regarding the plans, curriculum, content, outcomes, evaluation, teaching processes and more importantly the age group that they teach, and classroom teachers are not expected to teach preschool students. As such, school administrators who graduated from the classroom teaching department and have not received any education about preschool education should not be expected to manage preschool education organizations well.

From this perspective, research in the literature highlights that school administrators' displaying instructional leadership behaviors has effects on teachers and students. Since the end of the 1970s, the concept of instructional leadership has come to the agenda with the research conducted at successful and effective schools in Western countries. Research conducted on effective schools indicates that leadership is a significant factor in the effectiveness of schools, and a lot of research has been carried out to determine the characteristics of school administrators (Şişman, 2012).According to Gümüşeli (2014), instructional leadership and school effectiveness are closely related, and this close relationship stems from the fact that strong instructional leadership has important effects on school achievement and effectiveness. In a study conducted by Daresh and Ching Jen (1985), school administrators' instructional leadership behaviors were seen to be at a higher level in the favor of effective schools and that instructional leadership was a critical factor in school effectiveness. Furthermore, they propose some suggestions to support pre-service training of school administrators, their selection, and in-service training.

According to Şişman (2004), instructional leadership specifies the behaviors that both school administrators display themselves and have them displayed through affecting other people in order to reach desired outcomes. Findley and Findley (1992) define it as a leadership area which requires school administrators to deal with students, teachers, instructional program and teaching-learning processes directly. According to Krug (1992), instructional leadership is to put knowledge into practice in problem-solving and achieving school goals through other people. Consistently, Summak and Şahin (2013) define it as a leadership approach which covers all of the instructional activities and involves teachers in this process to carry out the activities. 
One of the most comprehensive studies on instructional leadership was conducted by Hallinger and Murphy in 1985, and school administrators' instructional leadership behaviors were tried to be determined. According to Hallinger and Murphy (1985), instructional leadership is a peculiar type of leadership for schools which specifies the activities related to the curriculum, academic achievement and teaching processes as the focal point.

Aksoy and Iş1k (2008) suggest that a school administrator who is an instructional leader should be able to direct the power of students, teachers, and community towards the goals of the school in order to enhance the quality of instruction. Can (2007) proposes that the school administrator as an instructional leader has a range of functions extending from participation in curriculum development to sharing the goals and activities with the environment starting from the parents. Aktepe and Buluç (2014) note that school administrators' instructional leadership behaviors are of critical importance in terms of effectively implementing the curriculum, cultivating learning and thereby boosting organizational performance. According to Aksoyalp (2010), in order for education to reach its goals, the school administrator should be a leader who is ready for developing a vision for the school, generating a mission for the school, bringing in novelties and accounting for what $\mathrm{s} / \mathrm{he}$ has done.

The dimensions of instructional leadership were determined to be 6 in the meta-analytic study of Kış (2013). These are; defining the mission, creating a learning climate, managing curriculum and instruction, developing the school staff, providing resources for learning and supervising-evaluating teachers.

Mission identifies the basic tasks that an organization has to carry out to realize the purpose of its existence. Defining the mission of the school is one of the most critical tasks of school administrators. The instructional leader clearly defines the mission of the school. In instructional leadership, it is aimed to develop a common mission which depends on stronger values (Çelik, 1999). According to Sayın (2010), there must be specific goals that schools target to reach as this is valid for every instructional activity.

Managing curriculum and instruction requires coordinating curriculum, monitoring student achievement, supervising instruction and evaluation. Çelebi (2009) notes that school administrators' and teachers' organizing curriculum regulated via educational policies in accordance with school culture may make significant contributions to the functionality of the curricula during instructional processes. Akdağ (2009) also proposes that in order for school administrators to achieve school goals, they must monitor and evaluate school achievement and student performance continuously and take required measures regarding these issues (cf. Şahin, 2011). T1kir (2005) states that school administrators need to monitor student achievement and thereby identify the students who need special or gifted education and the ones have low exam scores and develop appropriate programs and measures for them.

Taymaz (2003) argues that the supervision and evaluation dimensions of instructional leadership are critical for the achievement of school goals, and notes that the supervision of the instructional process can be an indicator of to what level the school goals are reached. Furthermore, Ergen (2009) proposes that instructional activities are the fundamental activities in terms of reaching school goals, and therefore supervising and evaluating these activities 
fall into school administrators' instructional leadership spectrum. Building on these deliberations and explanations, it can be stated that school administrators are expected to observe and evaluate school achievement, students' and teachers' performance, and appropriately take measures when needed in order to achieve school goals (Tatlioğlu \& Okyay, 2012).

According to Bamburg and Andrews (1990), the school administrator as a resource-providing instructional leader organizes the personnel and resources in order to realize the school mission and goals. The leader has the required knowledge and skills in terms of curriculum and instruction (Özdemir and Sezgin, 2002). Consistently, Yörük and Akdağ (2010) suggest that the school administrator as the instructional resource directly deals with the development of instructional environment by effectively communicating with teachers and promoting their use of instructional materials and new instructional strategies.

Demiriz et al. (2003) specify that a well-equipped and orderly learning atmosphere provides the ease for work for teachers as well as students. This is because teachers who are not faced with the lack of physical materials can spend more time with students and deal with them individually; and teachers can work there with pleasure, feel occupational satisfaction and increase their performance.

Hallinger's (1992) work entitled “The Evolving Role of American Principals: From Managerial to Instructional to Transformational Leaders" traces the trends in the evolution of school leadership in the USA from the 1960s to 1992. Three roles that emerged in this period and affected school principalship were investigated: the program manager, instructional leader, and transformational leader. Hallinger's study indicates that instructional leadership and curriculum management have been among the most frequently searched topics in recent years. Thus, in this research, these two topics are examined and the role of preschool administrators' knowledge about preschool curriculum is examined in terms of displaying instructional leadership behaviors. At this point, it is required to remember the elements of the curriculum and associate them with the dimensions of instructional leadership.

As known, the curriculum is a set of learning experiences that are provided for students in or outside the school through planned activities. In the curriculum, there are four fundamental elements. These are goal, content, learning-teaching experiences/processes and evaluation (Demirel \& Kaya, 2014).

When the elements of the curriculum and instructional leadership dimensions are examined, it can be stated that the goal element is the phase of determining the goal of the curriculum. Defining the mission dimension of instructional leadership refers to the existential goal of the organization. Therefore, it may be suggested that the goal element of the curriculum is related with defining the mission dimension of instructional leadership.

The content element of the curriculum requires making plans and programs and includes courses and subjects, and the managing curriculum and instruction dimension of instructional leadership also requires planning the curriculum and coordination. For this reason, the 
content element of the curriculum can be said to be related with the managing curriculum and instruction dimension of instructional leadership.

Şahin (2005) notes that the processes in the educational environment, as an element of the quality management process in education, are the venues where most of the time and resources are used. The processes in the educational environment cover learning activities, developing learning materials, planning the time for activities, teachers' in-service training, and cultural and sports activities.

The learning and teaching experiences element of the curriculum identifies all of the methods, techniques, materials and tools that teachers use during the educational and instructional process. The providing resources for learning dimension of instructional leadership requires the promotion of using new instructional materials and strategies, developing the learning environment and organizing the personnel and resources, which may indicate that this dimension is linked to the learning and teaching experiences element of the curriculum. Moreover, the learning and teaching experiences element of the curriculum is defined as all of the methods and techniques teachers use and the learning activities carried out in the classroom. As such, the managing curriculum and instruction dimension of instructional leadership requires the functioning and management of the school curriculum and observing the activities. This element of the curriculum and this dimension of instructional leadership may have a relationship as well.

The evaluation dimension of the curriculum covers supervising and evaluating the curriculum, and the managing curriculum and instruction dimension of instructional leadership refers to supervising and evaluating instruction and monitoring student achievement, which may mean that this element and the said dimension of instructional leadership are related. The elements of the curriculum and the related instructional leadership dimensions are presented in Table1. 
Table 1. The relationship between the elements of the curriculum and instructional leadership

The Elements of the Curriculum

Goal (determining the goal of the curriculum)

\section{The Dimensions of Instructional leadership}

Defining the Mission (defining the goal of the organization)

Content (Making plans and programs-course and Managing Curriculum and Instruction (planning topics) and coordinating the curriculum)

\begin{tabular}{|c|c|c|}
\hline \multirow{3}{*}{$\begin{array}{l}\text { Learning-Teaching } \\
\text { Experiences }\end{array}$} & $\begin{array}{l}\text { All of the methods } \\
\text { and techniques and }\end{array}$ & $\begin{array}{l}\text { Managing Curriculum and Instruction (the } \\
\text { functioning and management of the curriculum) }\end{array}$ \\
\hline & teaching activities & \\
\hline & $\begin{array}{l}\text { Providing } \\
\text { instructional tools } \\
\text { and materials }\end{array}$ & $\begin{array}{l}\text { Providing Resources for Learning (developing } \\
\text { the learning environment and organizing } \\
\text { resources) }\end{array}$ \\
\hline \multicolumn{2}{|c|}{$\begin{array}{l}\text { Evaluation(the quality check of education, to } \\
\text { what level the goals are reached?) }\end{array}$} & $\begin{array}{l}\text { Managing Curriculum and Instruction } \\
\text { (supervising instruction-evaluation, and } \\
\text { monitoring student achievement) }\end{array}$ \\
\hline
\end{tabular}

With this in mind, the researchers aimed at revealing the significance of preschool and primary school administrators' knowledge about the preschool curriculum in terms of displaying instructional leadership behaviors.

\section{Method}

In this research, a qualitative methodology which helps to unearth individuals' standpoints, experiences, feelings, and perceptions (Yıldırım and Şimşek, 2008)was used. Phenomenology was used as the research design in the study. This design focuses on the phenomena that we are aware of but do not have an in-depth understanding of them. It can be used in research which aims at investigating the phenomena which are known but not perceived comprehensively (cited from Yıldırım and Şimşek, 2013 by Çetin and Dikici, 2014).

Interviews were conducted with the participants after collecting data through a structured form. First of all, the data were collected from the participants via the form consisting of five main questions. Then interviews were held in order to obtain rich information about the research topic, learn the reasons behind participants' perceptions and carry out a comprehensive analysis.

\section{Study group}

Maximum variation sampling technique was used to select the participants from among preschool teachers and administrators working at schools tied to the Provincial Directorate 
National Education of Kilis Province. Maximum variation sampling encompasses the selection of information-rich cases to conduct in-depth research. This sampling technique enables researchers to choose the sample from different cases with regard to the problem situation (Büyüköztürk, 2012). In this research, preschool teachers and administrators working at kindergartens located in socio-economically different areas were withdrawn in order to enhance participant variation.

The participants were chosen from among volunteered teachers and administrators after getting their approved consent. Permission was also taken from the Provincial Directorate of National Education in Kilis prior to the data collection. Purposeful sampling technique was used to reach information-rich interviewees. A total of 20 preschool teachers and 10 school administrators participated in the first round of the data collection. Nine of the teachers were working at kindergartens, while the rest were working at preschool classes opened up within primary schools. Of the administrators, four were working at kindergartens and six were primary school administrators. Kindergarten administrators were the graduates of the preschool education departments. The other administrators graduated from the classroom teaching departments. Two preschool administrators were female, and two were male. Among primary school administrators, five were male, and one was female. All of the teachers interviewed were female. Preschool administrators' ages were between 24-40 years, and those of the primary school administrators were between $27-41$ years. The age interval of preschool teachers was between 27-41 years, but the age interval of the teachers working at primary schools was between $25-45$ years.

The second interview consisted of 12 preschool teachers (all female) and four school administrators (two males, two females). Six of the participating teachers were working at kindergartens, and six teachers were working at preschool classes of primary schools. Two of the administrators were working at kindergartens, while two of them were managing primary schools. The administrators of kindergartens were the graduates of preschool education departments, and primary school administrators graduated from classroom teaching departments. The administrators' ages ranged between 32-55 years; the ages of the teachers ranged between $25-40$ years.

\section{Data collection tool}

A semi-structured form developed by the researchers was used in the research. In order to develop the form, the relevant literature on instructional leadership, questionnaires, and scales were reviewed. The form consisted of five open-ended questions and probes developed in the light of three out of the six dimensions of instructional leadership (Defining the mission, managing curriculum and instruction, and providing resources for learning) which were directly related to the curriculum as suggested in Kış's (2013) meta-analytic study. The questions included in the interview protocol are presented below.

Q1.Teacher: Do you believe your school administrator has adequate knowledge about the basic goals and importance of preschool education identified by the Ministry of National Education (MoNE)? 
Q1.Administrator: Do you believe you have adequate knowledge about the basic goals and importance of preschool education identified by the MoNE?

Q2.Teacher: Do you think your school administrator makes sufficient contribution to the development of daily and monthly plans in order for the preschool curriculum reach its goals?

Q2.Administrator: Do you think you make sufficient contribution to the development of daily and monthly plans in order for the preschool curriculum reach its goals?

Q3.Teacher: Do you think your school administrator makes sufficient contribution to the formation of the physical instructional environment (providing resources such as tables, chairs, closets, shelves, and bulletin boards etc.) required for the attainment of the goals of preschool education?

Q3.Administrator: Do you think you make sufficient contribution to the formation of the physical instructional environment (providing resources such as tables, chairs, closets, shelves, and bulletin boards etc.) required for the attainment of the goals of preschool education?

Q4.Teacher: Do you think your school administrator makes sufficient contribution to the provision of the instructional materials (toys, educative materials, books, music sets, science and technology materials etc.)required for the attainment of the goals of preschool education?

Q4.Administrator: Do you think you make sufficient contribution to the provision of the instructional materials (toys, educative materials, books, music sets, science and technology materials etc.)required for the attainment of the goals of preschool education?

Q5.Teacher: Do you think your school administrator makes sufficient contribution to the proper evaluation of the instructional process required for the attainment of the goals of preschool education?

Q5.Administrator: Do you think you make sufficient contribution to the proper evaluation of the instructional process required for the attainment of the goals of preschool education?

The questions included in the semi-structured interview protocol were used to collect the data. Required permissions were taken from the Provincial Directorate of National Education of Kilis province before holding the interviews; the participants were informed about the purpose and significance of the study, and their consent was taken for their voluntary participation. The data were gathered from the participants in written form by individual interviews, and each interview lasted 50 minutes on average. The forms were filled out by the participants and entered into the computers by the researchers. The modality and flow of the questions was changed based on the mimics and gestures of the participants while answering the questions. Some probes were also utilized to collect more comprehensive information. Following the first round of data collection, new interviews were held with the participants to reveal their thoughts and perceptions in detail. A second interview form consisting of four open-ended questions was used. The questions were representing the ones in the first round of data collection. A sample question was as follows: "To the administrators: What kind of contributions do you believe your knowledge about the elements of preschool curriculum 
(goal, content, teaching-learning processes and evaluation) and the significance of preschool education can make contribution to the effective operation of the preschool education process and attainment of the goals of preschool education?"

\section{Data analysis}

The content analysis technique was used in the analysis of the data. In the content analysis, similar data are brought together around certain concepts and themes and interpreted in a way that the readers can understand (Yıldırım and Şimşek, 2008). Furthermore, Yıldırım and Şimşek (2011) suggest that if there exists a theoretical or conceptual framework laying the foundation of the research, it is possible to make a list of themes and codes, and then the emerging concepts and codes can be added to the list prepared. Thus, in this research, the three dimensions of instructional leadership which were put in Kış's (2013) study, that is, defining the mission, managing curriculum and instruction, and providing resources for learning, were determined as themes in order to benefit from the theoretical framework related to the research topic. Conceptual coding was done according to the concepts emerged from the data in the light of the data obtained from the participants.

The answers to the questions in the form were read and analyzed, coded, and then grouped under these themes. During the thematic coding, it was paid attention to whether the emerging codes made integrity and meaningfully explained all of the themes.

\section{Validity and reliability}

\section{Internal Validity}

In order to enhance internal validity (credibility), the questions in the interview protocol were posed to 3 preschool teachers and 3 preschool administrators as a pilot implementation. After the required corrections, the form including the questions was checked by an expert in the field of educational sciences. The interviews lasted as long as sufficient data were collected, and a trustful environment was set up to collect the data soundly. Moreover, the participantswere listened to without any interference. The data collection process was examined with an expert, and it was decided that this approach was suitable for the research.

\section{External Validity}

External validity (transferability) was ensured through authentic quotations from the participants' views and thick descriptions.

\section{Internal Reliability}

The concepts were collected under related themes and placed in the tables without interpretations. The interviews were held in a serene and comfortable place, and required explanations were made in order for the participants to answer the questions properly. The errors that might stem from the researchers and the data collection tool were tried to be kept under control, and thus reliability was tried to be ensured.

In order to enhance internal reliability (consistency), the related literature was reviewed carefully before the analysis, and the themes and sub-themes were constructed in the light of 
the review. Another way to enhance internal reliability was to ensure consistency between independent coders (intercoder reliability). After the coding process, the coding carried out by 2 experienced researchers except for the researchers was compared with the coding done by the researchers. Involving more than one researcher, expressing the research process in depth and concisely, maintaining the raw data, and confirming the data in the research meet the reliability criteria (Yıldırım and Şimşek, 2008).

The Reliability $=$ Consensus/ (Consensus + Dissidence) $X 100$ formula was used in the coding of the transcripts by both researchersfor reliability (Miles \& Huberman, 1994). The agreement rate between both researchers was calculated as $82 \%$. According to Y1ldirım and Şimşek (2003), the agreement percentage equal to $70 \%$ is accepted as satisfactory in the calculation of reliability.

\section{External Reliability (Dependability)}

One of the measures taken to ensure external reliability in qualitative research is to provide sufficient descriptions regarding data collection and analysis methods (Yıldırım and Şimşek, 2011). In this sense, the researchers were dedicated to increasing the quality of the interviews by interviewing with participants in a comfortable place. Detailed explanations were made regarding how the interviews were held; and the data were saved and analyzed.

\section{Findings}

\section{Findings about Defining the Mission Dimension}

Preschool teachers and preschool administrators' views about defining the mission dimension of instructional leadership are presented in Table 2.

Table 2. Teachers' and administrators' views on defining the mission dimension

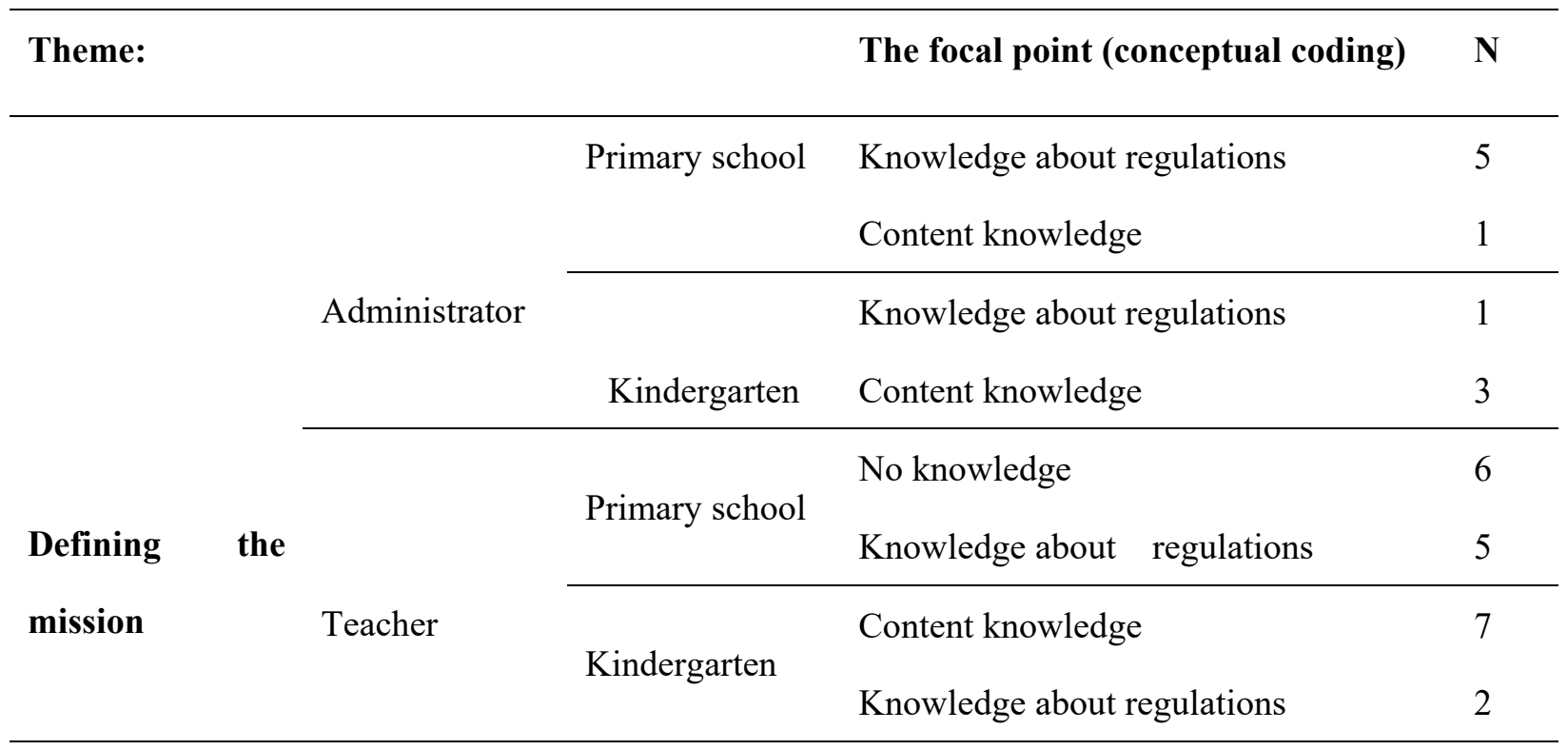


When the views of the primary school administrators regarding themselves in terms of defining the mission dimension, it can be seen that most of the administrators $(\mathrm{N}=5)$ noted that they had knowledge about the regulations about the preschool curriculum, while only one administrator stated that he had content knowledge on preschool education. One participant commented: "I have knowledge about the regulations. I review recent information and do research when required" (P-19). Most of the administrators suggested that professional development via seminars needs to be ensured in order to have sufficient knowledge about the preschool curriculum and that they must be researchers following latest developments in the field.

In the second round of data collection, primary school administrators proposed that having knowledge about the main purposes of preschool curriculum and its significance is critical for carrying out studies towards the goals of the organization and attaining them. Two participants commented that: "It is highly important for school administrators to have knowledge about the curriculum for the effective operation of the teaching and learning process. The administrator must constantly develop himself/herself with regard to the curriculum. If the administrator is knowledgeable about the curriculum, s/he can be more effective in realizing the school goals. S/he can make contributions to the provision of the required opportunities for the attainment of the goals $(P-15)$ ". "The administrator is one of the main elements for achieving the school goals. Teacher education is not sufficient to reach these goals, per se. Administrators' support is required in this process. If s/he does not have sufficient knowledge about the curriculum, s/he cannot be effective in this process. An administrator who knows the curriculum can understand teachers and their desires and reach the goals more easily ( $P-16)$."

Furthermore, nearly all of the kindergarten administrators $(\mathrm{N}=3)$ stated that they had knowledge about the preschool curriculum with regard to defining the mission dimension, and only one administrator specified that she had knowledge about the regulations concerning preschool education. One participant stated: "I believe that I have adequate knowledge. I find myself competent as I received secondary and tertiary education regarding preschool education" (P-18). Consistently, kindergarten administrators recommended that seminars must be organized in order for administrators to have adequate knowledge about the preschool curriculum; they must be researchers, and resources must be used at an optimum level. Consistent with what primary school administrators noted, kindergarten administrators stated that being knowledgeable about the main purposes of preschool curriculum and its significance may contribute to conducting studies regarding the school goals and attaining these goals effectively. The views of the administrators were as follows: "I think it is really important to have knowledge about the preschool curriculum. If I did not have the knowledge of preschool curriculum, I could not perceive the goals of the school properly and carry out studies for reaching the goals. I could not take required actions to eliminate improper activities. It would be very difficult to reach the goals (P-13)." "It is vital to have knowledge about the curriculum. A kindergarten administrator has to have knowledge about the significant and purpose of the curriculum. If the administrator does not have this knowledge, s/he cannot communicate the purpose, develop it and carry out the required studies. Thus, the 
administrator cannot do his/her job properly and explain the purpose of the curriculum (P-14)."

Some of the preschool teachers $(\mathrm{N}=6)$ working at primary schools with preschool classes stated that school administrators did not have knowledge about preschool education in terms of defining the mission, some others $(\mathrm{N}=5)$, however, noted that the administrators had knowledge about the regulations regarding preschool education. One teacher proposed that: "I do not think my school administrator has knowledge on preschool education. When a document and written paper are sent to the school, he tries to investigate it when required. He does not deal with the preschool education that much" (P-11). Another teacher specified that: "My school administrator has knowledge about preschool education, and he does research when needed" $(P-4)$. Preschool teachers working at primary schools suggested that professional development must be ensured via seminars to better equip the administrators with adequate knowledge about preschool education; it is required to develop their communication skills, communicate with teachers more, make them researchers and use resources in proper ways. In the second interviews, teachers working at preschool classes stated that having knowledge about the main purposes of the preschool curriculum and its significance is essential for preparing a curriculum based on the goals, implementing the curriculum without any problems, and achieving the goals of the curriculum. Some participants noted that: "An administrator who has knowledge about preschool curriculum can recognize children and the curriculum and comprehend the significant aspects for them. S/he will provide sufficient support for reaching the goals through (P-10)." "I think knowing the purpose and significance of preschool education is critical for the attainment of school goals. An administrator who is unaware of the purpose and significance of preschool education may give orders unconsciously and mislead the followers. This may impede reaching out the goals. Administrators' support is critical for operating the process consciously (P-7)."

According to the research findings, most of the preschool teachers $(\mathrm{N}=7)$ working at kindergartens accentuated that their administrators had content knowledge about preschool education, 2 of the teachers stated that the administrators had knowledge about the regulations regarding preschool education. One participant noted that: "As my school administrator graduated from the preschool education department, I think she has adequate knowledge about the preschool curriculum" (P-24). With regard to helping kindergarten administrators to have sufficient knowledge about the preschool curriculum, preschool teachers recommended that school administrators' communication skills need to be developed, they must communicate with teachers more, become experienced and act as researchers. They added in the second interviews that knowledge about preschool curriculum functions as a critical element in terms of attaining the goals in effective ways, recognizing and understanding teachers, supporting teachers, administrators' knowing the field and understanding it. Two participants opined: "The administrator can motivate teachers in the direction of school goals if s/he has knowledge about preschool education and can reach the goals in an efficient and short way. It is also critical for realizing the goals more effectively $(P-3)$."'Such an administrator knows the purpose and significance of preschool education. 
S/he is knowledgeable about the field and children's growth. Therefore, s/he supports teachers to reach the goals and also facilitates the implementation of the plans properly. S/he knows the curriculum has a flexible structure and understands teachers' goals more easily $(P-1) "$.

\section{Findings Regarding the Managing Curriculum and Instruction Dimension}

Preschool teachers' and preschool administrators' views about the managing curriculum and instruction dimension of instructional leadership are given in Table 3.

Table 3. Preschool teachers' and administrators' views about the managing curriculum and instruction dimension

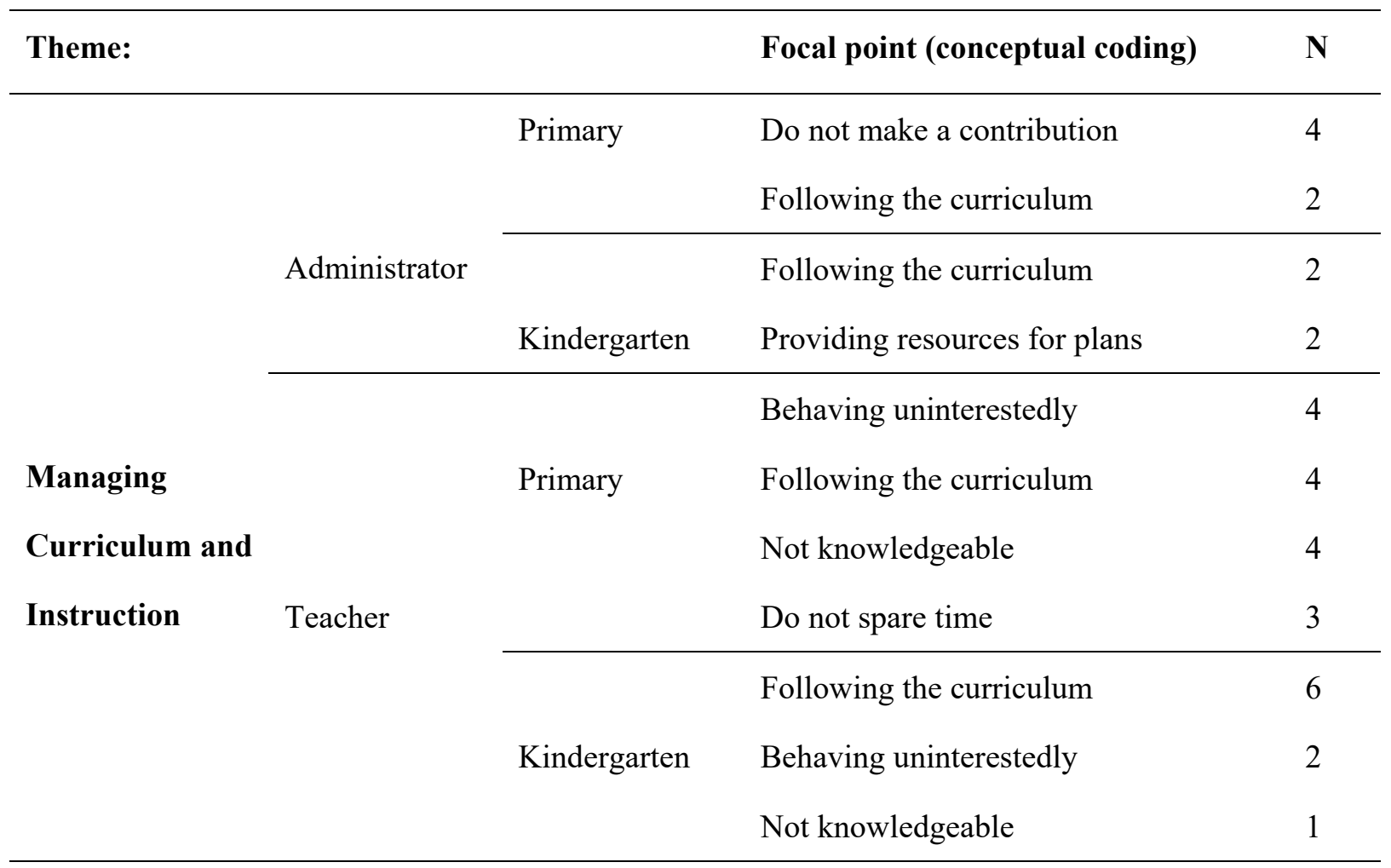

According to the managing curriculum and instruction dimension, when the views of the primary school administrators working at schools with preschool classes are examined, it can be observed that most of the administrators $(\mathrm{N}=4)$ noted that they could not contribute to managing curriculum and instruction as required, and 2 administrators stated that they followed the curriculum. One participant commented on this dimension: "As I do not have sufficient knowledge about preschool education and cannot find time to deal with it, teachers prepare the plans" (P-12). These administrators recommended that collaboration and communication must be increased, classroom visits must be made, and knowledge about preschool education must be owned in order to enhance administrators' competencies regarding this dimension. In the second interviews, primary school administrators noted that being knowledgeable about the content, goal, teaching-learning processes and evaluation elements of the curriculum is essential for making instruction more effective, establishing a right channel of communication with parents, teachers and students, recognizing and 
understanding students and teachers, guiding and motivating teachers, grasping the purpose of the curriculum and consciously managing the curriculum, making objective and conscious evaluations. They supported their views as such: "I think an administrator must have knowledge about the curriculum in order to actively participate in preschool education. If not, s/he cannot support teachers in this regard and observe students appropriately. Thus, s/he cannot evaluate teachers properly. As s/he does not know the purpose of the activities, s/he cannot understand what the teacher wants to do in the classroom... (P-16)." Another administrator gave a striking example of having such knowledge: "It is very significant to have this knowledge. A few months ago, as I did not have adequate knowledge about the curriculum, I tended to evaluate the teacher improperly. When I entered the classroom, students were playing on themselves, and I thought that the teacher did not deal with them; whereas, this was a part of the educational process. I searched and learned this later. In order to solve the problems with parents, if it happens, this knowledge is critical. Some parents want things that are not really conscious. At these times, it is our job to communicate with them. An administrator who knows the curriculum understands the teacher better and guides him/her. The teacher also knows that the administrator supports him/her and works more efficiently (P-15)".

With regard to preschool teachers' views on the managing curriculum and instruction dimension, it can be seen that preschool administrators followed the curriculum $(\mathrm{N}=2)$ and provided resources for planning $(\mathrm{N}=2)$. One participant proposed that: "I follow the process by making classroom visits. We try to eliminate the shortcomings after receiving feedback" $(P-19)$. Preschool administrators made similar suggestions to increase their contributions to managing curriculum and instruction with primary school administrators. Increasing collaboration and communication, making classroom visits and being knowledgeable about preschool education were seen to be necessary. Kindergarten administrators believed that knowledge about the elements of the curriculum is highly important. It helps them to make appropriate, objective and conscious evaluations, understand and recognize teachers, guide teachers, manage the educational process consciously and share with teachers more useful things. The views of an administrator were as follows: "The administrator must be well-equipped about the curriculum. If not, s/he cannot make proper evaluations. It depends on the administrator's consciousness to understand the teacher, recognize students and evaluate them and attain the results successfully $(P-14)$."

When the views of the teachers working at primary schools with preschool classes with regard to the managing curriculum and instruction dimension are investigated, it can be observed that teachers' views about their administrators were negative. Research findings indicated that the administrators were uninterested in preschool education $(\mathrm{N}=4)$, they were not knowledgeable about preschool education $(\mathrm{N}=4)$, they only followed the curriculum $(\mathrm{N}=4)$, and they did not spend enough time for preschool education $(\mathrm{N}=3)$. One participant commented: "Our school administrators is very interested and try to help us. However, as his field was not preschool education, he is incompetent in terms of knowledge and skills" (P-9). Another one argued that "My school administrator is not interested in preschool education and does not make classroom visits. For this reason, he does not make much contribution to 
planning and evaluating education and instruction" ( $P-8)$. Preschool teachers in the primary schools recommended that the administrators must make more classroom visits, increase collaboration and communication, beware of the importance of preschool education, and spare time for preschool education. The teachers working at preschool classes of primary schools accentuated that it is significant to have knowledge about the elements of the curriculum for recognizing and understanding teachers, making conscious evaluations, guiding teachers, setting up a sound communication with parents, students and teachers, managing the educational process properly, monitoring student achievement, understanding the purpose of the curriculum and its activities, supporting the practices, and solving the problems easily. They focused on these aspects in the interviews: "An administrator who does not know the curriculum cannot manage the instructional process appropriately, supervise instruction and evaluate teachers. This may lead to some other problems in the process. If s/he knows the curriculum, s/he can coordinate the curriculum and enhance its applicability. Thus, a more quality and suitable education can be given. Furthermore, it can lead teachers to do their jobs more effectively (P-12)." "If s/he does not have this knowledge, s/he cannot understand the activities and what is done in the classroom. Therefore, some problems may be faced in the evaluation process. Primary school administrators do not know the curriculum well and cannot make sound evaluations. This knowledge is important for communicating with parents. S/he can lead the parents more properly and solve the problems easily (P-10)."

Most of the teachers working at kindergartens specified that their administrators followed the curriculum $(\mathrm{N}=5)$, they were uninterested in preschool education $(\mathrm{N}=2)$, and they were not knowledgeable about preschool education $(\mathrm{N}=1)$. One teacher stated that: "He follows the proper implementation of the goals and outcomes identified in the curriculum according to children's levels; we make joint evaluations" $(P-19)$. In order to enhance the administrators' contribution to the managing curriculum and instruction dimension, preschool teachers made the same recommendations with the ones working at primary schools: They must make classroom visits more frequently, courses and seminars must be held, they must deal with teachers more interestedly, and they must increase collaboration and communication. Preschool teachers working at kindergartens having knowledge about the elements of the curriculum is effective for making sound and conscious evaluations, recognizing and understanding teachers, recognizing and understanding children, guiding and motivating teachers, having a sound communication with students, parents and teachers, implementing the plans effectively, knowing the classroom atmosphere, solving the problems easily and enhancing the meaningfulness of the process. Some teachers commented: "I think this knowledge is critical for supervising teachers, seeing the efficiency, and monitoring achievement. Administrators who do not have this knowledge cannot interfere with the process and eliminate the problems (P-5)". "If the administrator lacks this knowledge, s/he cannot evaluate the instructional process and teachers properly as s/he does not know teachers' readiness and what needs to be done in the program. Knowledge about the curriculum will lead administrators to support teachers in every phase and increase the effectiveness of the process through collaboration $(P-4)$. "This knowledge is very important... for example, I share the problems in my classroom with my administrator because he is 


\section{Mll Macrothink}

Journal of Studies in Education

ISSN 2162-6952

2017, Vol. 7, No. 3

knowledgeable about the curriculum; he supports me and we find solutions more easily $(P-2) "$.

\section{Findings Regarding the Providing Resources for Learning Dimension}

Preschool teachers' and administrators' views about the providing resources for learning dimension are presented in Table 4.

Table 4. Teachers' and administrators' views about the providing resources for learning dimension

Theme:

\begin{tabular}{|c|c|c|c|}
\hline & & Focal point (conceptual coding) & $\mathbf{N}$ \\
\hline \multirow{9}{*}{ Administrator } & \multirow{5}{*}{ Primary school } & Not making sufficient contribution & 4 \\
\hline & & Making sufficient contribution & 2 \\
\hline & & Getting support from other schools & 2 \\
\hline & & Getting support from parents & 1 \\
\hline & & Getting support from the PDNE & 1 \\
\hline & \multirow{4}{*}{ Kindergarten } & Making sufficient contribution & 4 \\
\hline & & Getting support from the PDNE & 2 \\
\hline & & Getting support from other schools & 1 \\
\hline & & Getting support from parents & 1 \\
\hline \multirow{10}{*}{ Teacher } & \multirow{5}{*}{ Primary school } & Behaving uninterestedly & 11 \\
\hline & & Getting support from the PDNE & 3 \\
\hline & & Getting support from other schools & 3 \\
\hline & & Being unknowledgeable & 3 \\
\hline & & Not making contribution & 2 \\
\hline & \multirow{5}{*}{ Kindergarten } & Making sufficient contribution & 5 \\
\hline & & Behaving interestedly & 3 \\
\hline & & Getting support from the PDNE & 2 \\
\hline & & Getting support from other schools & 2 \\
\hline & & Not making sufficient contribution & 2 \\
\hline
\end{tabular}

When the views of the primary school administrators regarding themselves are examined, it can be seen that they found themselves competent in terms of making sufficient contribution $(\mathrm{N}=2)$, getting support from other schools $(\mathrm{N}=2)$, the parents $(\mathrm{N}=1)$, and the Provincial Directorate of National Education (PDNE); however, some administrators argued that they 
$(\mathrm{N}=4)$ were not able to make sufficient contribution. This shows that most of the administrators believed that they were competent in terms of providing resources for learning. The views of the administrators corroborate this situation. One administrator added: "We try to provide the required materials. We get support from the parents and the PDNE" (P-3). However, another administrator noted that he could not provide the required support: "We try to provide support, but we cannot do that as required due to monetary problems" (P-28). Primary school administrators suggested that they must conceive the importance of preschool education and get support from the PDNE; school budget must be increased, and more support must be taken from other schools in order to enhance the contributions to the providing resources for learning dimension. In the second interviews, primary school teachers believed that having knowledge about the teaching-learning processes dimension of the curriculum can contribute to understanding the purposes and functions of the materials, realizing the needs, making right choices about the materials, and establishing an effective educational atmosphere. Two administrators stated that: "The administrators who do not know anything about the curriculum see materials as toys directly and do not know their educative characteristics. Such administrators may see the materials as unnecessary and may not set up the atmosphere (P-15)". "Creating an educational atmosphere is one of the most significant tasks of the administrators. Those who do not own the knowledge about the curriculum cannot recognize the materials and understand the needs (P-16)".

The findings regarding kindergarten administrators' views about the providing resources for learning dimension were that they argued that they made sufficient contribution $(N=4)$, got support from the PDNE $(\mathrm{N}=2)$, other schools $(\mathrm{N}=1)$ and parents $(\mathrm{N}=1)$. According to these findings, in terms of providing resources for learning, kindergarten administrators did not face with severe challenges, and they believed that they provided the required materials and resources at a sufficient level for the functioning of teaching and learning processes. One administrator stated that: "We inform the Provincial Directorate of National Education when needed. Our deficiencies in materials are removed in this way." (P-22). Kindergarten administrators made the same recommendations with primary school administrators as to increase their contribution to the providing resources for learning dimension. They suggested that the importance of preschool education must be conceived, and the support from the PDNE and the school budget must be increased. Kindergarten administrators thought that being knowledgeable about teaching-learning processes is required to understand the needs, choosing right materials, knowing the purposes and functions of the materials and making the learning environment more effective. The views of the participants were as follows: "If the administrator has knowledge about the curriculum, s/he can make conscious choices about materials and tools. S/he will be aware of that the materials are needed. S/he will become a researcher and contribute to the establishment of a productive learning atmosphere (P-13)". "Knowledge about the curriculum is important for the formation of the learning atmosphere. The administrators must meet teachers' desires and set up the atmosphere... (P-14)".

In terms of providing resources for learning, preschool teachers working at primary schools with preschool classes proposed various views, and most of them were negative. They asserted that their administrators did not pay sufficient attention to preschool education and 
that the lacking aspects of preschool education were not eliminated properly. Their views were; behaving uninterestedly $(\mathrm{N}=11)$, getting support from the PDNE $(\mathrm{N}=3)$, getting support from other schools $(\mathrm{N}=3)$, not being knowledgeable $(\mathrm{N}=3)$, and not making any contribution $(\mathrm{N}=2)$. Two teachers believed that their administrators could not make any contribution to preschool education due to the lack of the budget. One teacher accentuated: "Our administrator allocates most of the budget for primary and middle schools. He uses the budget for preschool classes for the primary school as well and does not deal with the deficiencies of preschool classes. Required correspondence is not carried out for the deficiencies in materials." (P-14). Another participant noted that: "The administrator cannot make any contribution because of the financial problems and his/her indifference." (P-26). With regard to this dimension, preschool teachers stated that primary school administrators must be informed about the preschool curriculum, the PDNE must provide more support for preschool education, and the administrators must pay more attention to preschool education. Furthermore, the other suggestions were that teachers and administrators must collaborate more, the revenues must be used efficiently, more support must be taken from schools, and the school budget must be increased. It was revealed that teachers working at preschool classes of primary schools believed that knowledge about the teaching-learning processes element of the curriculum facilitates the formation of an effective learning environment, knowing the purposes of the materials and providing them properly, meeting the needs and deficiencies. Some of them stated that: "An administrator who is knowledgeable about the curriculum cannot choose toys and materials consciously. S/he can form a more productive learning environment (P-8)". "An unknowledgeable administrator may not know the purposes of the materials and provide materials that are suitable for children's level. However, a knowledgeable administrator can conceive how necessary the materials are $(P-10)$ ". "An administrator who does not have this knowledge cannot meet teachers' needs, may provide two materials which are used to teach the same concept and form a productive classroom environment (P-7)".

Most of the teachers working at kindergartens thought that their administrators contributed to preschool education sufficiently $(\mathrm{N}=5)$. They believed that they behaved interestedly $(\mathrm{N}=3)$, got support from the PDNE ( $=2)$, received support from other schools $(\mathrm{N}=2)$, and could not make any contribution to preschool education $(\mathrm{N}=2)$. Only two teachers held negative views about their administrators for the providing resources for learning dimension. Some participants' views were as follows: "The materials which are lacking are determined and properly provided. We communicate with our administrator, and get support from him in terms of instruction, methods, techniques, and materials." (P-24). "The collected revenues are not used very efficiently. Also, our administrator behaves uninterestedly. For this reason, we cannot receive enough support." $(P-26)$. The recommendations of preschool teachers were similar to those of the teachers working at primary schools with preschool classes. They stated that the PDNE must support preschool education more, there must be communication between teachers and administrators, the revenues must be used efficiently, the school budget must be increased, and there must be acollaboration between administrators, teachers, and parents. Consistent with teachers working at preschool classes, preschool teachers working at kindergartens believed that knowledge about the teaching-learning processes element of the 
curriculum is important for understanding the needs, knowing the purposes and functions of the materials, providing materials properly, eliminating the deficiencies, and providing resources from proper organizations. They supported their views as follows: "If the administrator does not have knowledge about the curriculum, s/he cannot communicate with the related organizations and cannot provide resources for them... An administrator who has this knowledge can understand for what reasons the materials are used (P-2)". "An administrator who has this knowledge can see the deficiencies in the learning environment and support teachers to eliminate these deficiencies. S/he is aware of the necessity of the materials and does not see the needs as costs. S/he also knows that these deficiencies may cause negative results for children (P-3)'”.

\section{Discussion and Conclusion}

According to the research results, it may be suggested that most of the primary school administrators did not have adequate knowledge about the preschool curriculum, and therefore, it seemed that they needed support for defining the mission dimension when the administrators' evaluations regarding themselves and the recommendations they made to enhance their competencies for defining the mission dimension of instructional leadership were examined. The teachers working at primary schools with preschool classes stated their views regarding their administrators and made recommendations. In accordance with the views and recommendations, the administrators can be said not to have adequate knowledge about the preschool curriculum, and for this reason, they could not provide sufficient support for preschool education, and the teachers complained about this situation. Kerem and Cömert (2004) found similar results in their study investigating the general problems of preschool education, and they revealed that school administrators did not have sufficient knowledge about preschool education, and they were indifferent to meeting teachers' desires and needs. The Kerem and Cömert (2004) study corroborates the results obtained in the current study. However, both preschool teachers and kindergarten administrators had positive views about defining mission dimension. The findings of the research demonstrated that primary school administrators were not knowledgeable about the preschool curriculum, but almost all of the kindergarten administrators were the graduates of the preschool education departments and had related content knowledge.

Drawing on teachers' views, it can be suggested that the administrators who did not have adequate knowledge about preschool education were incompetent in defining mission dimension, and in this sense, they could not make sufficient contribution to the process covering the determination of the curricular goals. However, the administrators who had adequate knowledge about the preschool curriculum were more successful in defining mission dimension and they could make sufficient contribution to the goal determination process of the curriculum. The workshop report published in 2004 also supports these results. In the Haktanır et al.'s (2004) workshop report, the problems facing the field of preschool education were compiled. The report proposed that there were problems with the qualifications of the staff working both at state and private preschool education institutions, primary school administrators and supervisors did not have adequate knowledge about preschool education and that there were physical infrastructural deficiencies. The teachers 
who worked under these conditions could not find opportunities to develop themselves. In addition, in-service training opportunities were not sufficient. In the second interviews held to enhance the results of the research, it was revealed that primary school administrators and kindergarten administrators stated that administrators' having knowledge about the goals and significance of preschool education is critical for explaining and developing the goals of preschool education, and this is significant for an effective management. The views of the teachers working at preschool classes of primary schools and those working at kindergartens were seen to be consistent with regard to the same dimension. Based on this finding, it can be suggested that teachers and administrators believed that having knowledge about the goals and significance of preschool education is important for administrators' enhancing their effectiveness in defining the mission dimension.

Primary school administrators' views on themselves regarding managing curriculum and instruction and the recommendations they made were investigated. The research results indicated that most of the primary school administrators did not have sufficient knowledge about the preschool curriculum with regard to the managing curriculum and instruction dimension of instructional leadership or did not have enough time to contribute to preschool education sufficiently. In his doctoral dissertation entitled "Primary School Administrators' Instructional Leadership Roles and the Challenges They Face", Sağır (2011) found similar results and revealed that school administrators had the most important problems in the 'management of the curriculum and instructional process' dimension. Preschool administrators found themselves competent in managing curriculum and instruction, but primary school administrators made similar suggestions, and this underscores the importance of having knowledge about preschool education and of the communication between teachers and administrators.

According to the views and suggestions of the preschool teachers working at primary schools, primary school administrators did not attach importance to preschool education at thedesired level, and could not make significant contributions to managing curriculum and instruction. However, the views of preschool teachers working at kindergartens were seen to be mostly positive in their evaluations of the administrators. These teachers also made similar recommendations with the ones working at preschool classes of the primary schools, which shows the importance of knowledge about the preschool curriculum, collaboration, and communication. In the light of these data, due to the fact that primary school administrators did not have adequate knowledge about the preschool curriculum and give sufficient importance to preschool education, it may be suggested that they could not make sufficient contribution to managing curriculum and instruction, that is, the content of the curriculum, the teaching-learning process, and the evaluation process sufficiently. However, kindergarten administrators had adequate knowledge about preschool education, gave importance to preschool education and spent time for preschool education, and therefore they made more contributions to the managing curriculum and instruction dimension, namely, the content of the curriculum, the teaching and learning process, and the evaluation process when compared to primary school administrators. It was unearthed that both teachers and administrators had similar views about having knowledge about the goal, content, teaching-learning processes 
and evaluation elements of the curriculum with regard to the managing curriculum and instruction dimension of instructional leadership. All of the participants believed that having this knowledge of the elements of the curriculum can enhance the effectiveness of the administrators in this dimension.

According to the results, it can be stated that there were deficiencies at primary schools in terms of the providing resources for learning dimension of instructional leadership, while there were almost no problems at kindergartens. It may not be wrong to suggest that the deficiencies stemmed from school administrators' being unknowledgeable about preschool education and not paying much attention to preschool education. Furthermore, the number of classes is a lot and varying at schools, and school administrators could not find time to deal with preschool education due to their busyness. Based on the results, it can be stated that primary school administrators did not have knowledge about the preschool curriculum and the importance of preschool education, which led to their incompetence in terms of forming a learning environment, organizing instructional resources and providing instructional materials. In addition to this, they could not contribute to the teaching-learning process which incorporates instructional methods, techniques, materials and tools sufficiently. On the other hand, kindergarten administrators were more knowledgeable about preschool education and aware of the importance of preschool education, and it can be suggested that they were more competent in terms of providing resources for learning. Teachers and administrators in both types of schools had positive thoughts about having knowledge about teaching-learning processes dimension of the curriculum, and they suggested that this knowledge is significant for the effectiveness in providing resources for learning. Drawing on this point, all of the participants agreed that this knowledge is important for enhancing the effectiveness of the providing resources for learning dimension.

In Atasavun's (1994) study, the issues leading to communication problems between kindergarten administrators and teachers were examined. There were problems between school administrators and teachers in terms of preparing yearly and daily plans, organizing trips, the lack of cleaning tasks in the school, playgrounds and the lack of tools-materials, and the imbalance between educational costs. When the results of Atasavun's study are investigated, it can be seen that the problems were generally associated with the managing curriculum and instruction and providing resources for learning dimensions of instructional leadership. In that research, it was recommended that preschool administrators and teachers must develop their behaviors related to human relations via in-service training seminars. The current study supports the findings which evidenced the problems about the managing curriculum and instruction and providing resources for learning dimensions of instructional leadership dimensions.

When the research results are examined, it can be noticed that preschool teachers employed at primary schools held negative views about their administrators' instructional leadership practices. An important portion of these teachers argued that their administrators did not have adequate knowledge about preschool education and give importance to preschool education, and they recommended that the administrators must be trained about preschool education. Preschool teachers working at kindergartens believed that their administrators had content 
knowledge about preschool education, and they made sufficient contribution to defining the mission, managing curriculum and instruction, and providing resources for learning. The points that preschool teachers focused most in order to develop instructional leadership were making frequent classroom visits, communicating with teachers properly, gaining experience, and increasing the support from the PDNE. In general terms, it can be seen that both primary school administrators and kindergarten administrators found themselves competent in many aspects and regarded themselves as instructional leaders. At this point, it may be suggested that the perceptions of preschool teachers working at primary schools and the administrators' perceptions of their instructional leadership skills were not consistent. Another research revealing similar results was conducted by Sözüeroğlu (2006). Sözüeroğlu's (2006) master's thesis entitled "Evaluation of Primary School Principals' Instructional Leadership Behaviors" concluded that primary school administrators conceived themselves as competent as instructional leaders; however, teachers perceived their administrators' instructional leadership at a lower level than administrators did in general. The study conducted by Gürocak and Hacıfazlıoğlu in 2012 aimed at investigating to what level school administrators carried out instructional leadership tasks based on preschool teachers' perceptions. It was concluded that teachers' perceptions of their principals were generally positive, unlike the results of the present study. Similarly, in Aksoy's (2006) study, the level of principals' displaying instructional leadership was detected to be high. Despite this, there were significant differences between school principals who attended in-service training and who did not in all of the dimensions of instructional leadership.

In the first interviews, preschool teachers' perceptions of their administrators and the administrators' perceptions regarding themselves were examined. In the second interviews, it was found that all of the teachers and administrators working at both organizations accentuated similar views about the importance of administrators' knowledge about the preschool curriculum in terms of instructional leadership practices.

This research concluded that the knowledge about the preschool curriculum was highly important in preschool administrators' instructional leadership practices. İş (2002) examined preschool administrators' competencies in achieving organizational goals and found that preschool administrators showed inadequate performance in terms of management by goals. He proposed that preschool education must be handled separately in the formal education process and that the administrators of these schools must be trained in accordance with the field of preschool education.

School administrators must have knowledge about the curriculum, content, goals, outcomes, instructional process, educational environment, evaluation, age groups and developmental characteristics related to preschool education in order to enhance the quality of preschool education and display instructional leadership which has become prominent in recent years.

\section{Suggestions}

Drawing on the result that primary school administrators did not have sufficient knowledge about the preschool curriculum, it may be suggested that primary school administrators must be trained in accordance with the preschool curriculum (goals, content, teaching-learning 
processes, and evaluation), age groups of children and developmental characteristics, and more importantly, the importance of preschool education.

It was detected that the problems faced in the providing resources for learning dimension resulted from financial deficiencies, and the participants suggested that the PDNE must support schools. In this sense, the Ministry of National Education must give more importance to preschool education and increase the budget allocated for preschool education.

The research results demonstrated that preschool teachers working at primary schools and some of the administrators believed that administrators could not spare time for preschool education and had heavy workloads. Based on these results, it may be suggested that kindergartens must be opened as independent schools and that the administrators must be chosen from among tho ones received education on preschool education because preschool administrators were seen to have better instructional leadership practices.

\section{References}

Ada, Ş., Küçükali, R., Akan, D., \& Dal, M.(2014). Okulöncesi eğitim kurumlarında yönetim sorunlar1. Middle Eastern \& African Journal of Educational Research, 12, 32-49.

Akdağ, G. A. (2009). İlköğretim Okul Müdürlerinin Öğretimsel Liderlik Davranışlarının Yeni Ilkögretim Müfredatının Uygulanmasındaki Etkililik Düzeyi,Yayınlanmamış Yüksek Lisans Tezi, Kocatepe Üniversitesi Sosyal Bilimler Enstitüsü, Afyon.

Aksoy, E. (2006). Illköğretim okulu yöneticilerinin öğretimsel liderlik rolleri, Yayınlanmış Yüksek Lisans Tezi, Onsekiz Mart Üniversitesi Sosyal Bilimler Enstitüsü, Çanakkale.

Aksoyalp,Y.(2010). 21. Yüzyılda okul yöneticisinin niteliği: Öğretim liderliği, Sakarya Üniversitesi Eğitim Fakültesi Dergisi, 20, 140-150.

Aktepe, V., \& Buluç, B. (2014). Sınıf öğretmenlerinin algılarına göre okul yöneticilerinin öğretim liderliği özelliklerinin değerlendirilmesi. Gazi Eğitim Fakültesi Dergisi, 34(2), 227-247

Atasavun, M. M. (1994). Okul öncesi ĕgitimde yönetmenler ile öğretmenler arasında ilişki bozukluklarl yaratan konular. Yayımlanmamış yüksek lisans tezi, Ankara Üniversitesi Sosyal Bilimler Enstitüsü, Ankara.

Bamburg J. D., \& Andrews.R.L , (1990), Instructional Leadership, School Goals, and Student Achievement. Exploring the Relationship Between Means and Ends. Eric, ED.319783.Büyüköztürk, Ş. (2012). Örnekleme yöntemleri. Retrieved from http://w3.balikesir.edu.tr/ msackes/wp/wp-content/uploads/2012/03/BAY-Final-Konulari.pdf

Can, N. (2007). İlköğretim okulu yöneticisinin bir ilköğretim lideri olarak yeni öğretim programlarının geliştirilmesi ve uygulanmasındaki yeterliliği.Eğitimde Kuram ve Uygulama,3(2), 228-244.

Çelebi, S. (2009). Özel ve kamu ilköğretim okullarında görev yapan müdürlerin göstermiş oldukları ögretim liderliği davranışlarına ilişkin öğretmenlerin ve müdür yardımcılarının 
algıları. Yüksek Lisans Tezi, Mersin Üniversitesi Sosyal Bilimler Enstitüsü Eğitim Bilimleri Anabilim Dal1, Mersin.

Çelik,V. (1999). Eğitimsel liderlik. Ankara: Pegem Yayınları.

Çetin, A., \& Dikici, R (2014). Eğitim bilimlerinde araştırma yöntemleri dersinin etkililiği. Kastamonu Ĕ̈itim Dergisi. 22(3), 981-994.

Dale, E.(1969). Management Theory and Practice. McGraw Book. p.19-89.

Daresh, J.C., \& Ching-Jen, L. (1985). High school principals perceptions of their instructional leadership behavior.Paper Presented at the Annual Meeting of the American Educational Research Assocition, 3-22.

Demirel,Ö., \& Kaya,Z.(2014). Ĕgitim bilimine giriş (9. Bask1). Ankara: Pegem Akademi

Demiriz, S. , Karadağ, A. \& Ulutaş, İ. (2003). Okul öncesi eğitim kurumlarında eğitim ortamı ve donanım. Ankara: Anı Yayınc1lık.

Ergen,Y.(2009). İlköğretim okulu müdürlerinin öğretimsel liderlik davranışlarının öğretmenlerin motivasyonu üzerindeki etkisi (Manisa ili örneği),Yüksek Lisans Tezi, Celal Bayar Üniversitesi Sosyal Bilimler Enstitüsü İlköğretim Ana Bilim Dalı, Manisa.

Findley B.., \& Findley D. (1992) Effective schools: The role of principal. Contemporary Education, 63(2), 100-104.

Gümüşeli,A.İ. (2014). Eğitim ve ögrretim yönetimi. Ankara: Pegem Akademi.

Gürocak, E.O., \& Hacıfazlıŏlu, Ö. (2012). Okul öncesi eğitim kurumu yöneticilerinin öğretim liderliği davranışlarına ilişkin öğretmen algıları. International Journal of Human Sciences, 9(2), 318-338.

Haktanır, G., Dinçer, Ç., Küçükturan, G., Turcan, A.İ., \& Şen, M. (10-11 February 2004). Okul öncesi eğitim sisteminde karşılaşılan sorunlar ve çözüm önerileri. Eğitim Bilimleri Bakış Açısıyla Eğitimin Güncel Sorunları ve Çözüm Önerileri Çalıştayı Yayımlanmamış Raporu, Ankara

Hallinger, P., \& Murphy, J. (1985). Assessing the instructional management behavior of principals. The Elementary School Journal, 2, 217-247. https://doi.org/10.1086/461445

Hallinger, P. (1992). The evolving role of American principals: From managerial to instructional to transformational leaders. Journal of Educational Administration, 30(3), 35-49. https://doi.org/10.1108/09578239210014306

İş, E. ( 2002). Okulöncesi eğitim kurumlarında görev yapan yöneticilerin kurumsal amaçları gerçekleştirmedeki yeterliliklerinin incelenmesi. Yüksek Lisans Tezi, Gaziantep Üniversitesi, Eğitim Bilimleri Enstitüsü, Gaziantep.

Katranc1, M. (2014). Okul öncesi eğitim ve önemi. In Seven, S. (Ed.),Okul öncesi eğitime giriş (pp.2-14). Ankara, Pegem Akademi. 


\section{Macrothink}

Journal of Studies in Education

ISSN 2162-6952

2017, Vol. 7, No. 3

Kerem, E. A., \& Cömert, D. (2003). Okul öncesi eğitimin sorunlarına genel bir bakış. Ĕ̆itim Araştırmaları Dergisi, 13, 29-35.

Kış, A.(2013). Okul müdürlerinin öğretimsel liderlik davranışlarını gösterme düzeylerine ilişkin yönetici ve ögretmen görüşlerine yönelik bir meta-analiz. Yayınlanmış Doktora Tezi. İnönü Üniversitesi Eğitim Bilimleri Enstitüsü Eğitim Yönetimi ve Denetimi Bilim Dal1,Malatya.

Krug, S. E. (1992). Instructional leadership: A constructivist perpective. Educational Administration Quarterly, 28(3), 430-443. https://doi.org/10.1177/0013161X92028003012

Miles, M., \& Huberman, M. (1994). An expanded sourcebook qualitative data analysis( $2^{\text {nd }}$ Edition). California: Sage Publications.

Özdemir Topaloğlu, A. (2009). Okulöncesi eğitim kurumlarında çalışan yöneticilerin örgütsel amaçları gerçekleştirmedeki yeterlilikleri. Yüksek Lisans tezi, Trakya Üniversitesi Sosyal Bilimler Enstitüsü, Edirne.

Özdemir, S., \& Sezgin, F. (2002). Etkili okullar ve öğretim liderliği.Sosyal Bilimler Dergisi, 267-282.

Poyraz, H., \& Dere, H. (2006). Okulöncesi eğitimin ilke ve yöntemleri( $3^{\text {rd }}$ Ed.). Ankara: Anı Yayıncilık.

Sağır, M. (2011). İlköğretim okulu yöneticilerinin öğretimsel liderlik rolleri ve karşılaştıkları sorunlar. Yayınlanmış Doktora Tezi, Abant İzzet Baysal Üniversitesi Sosyal Bilimler Enstitüsü, Bolu.

Sağır, M. (2015). Öğretimsel liderlik, In Konan, N. (Ed.). Eğitim yönetiminde yeni liderlik yaklaşımları, (6. Bölüm, ss.133-152 ). Ankara, Pegem Akademi.

Sayın, E. (2010). Öğretimsel liderlik ve ilköğretim okulu yöneticileri üzerine bir araştırma. Yüksek Lisans Tezi, Çanakkale Onsekiz Mart Üniversitesi Sosyal Bilimler Enstitüsü İşletme Ana Bilim Dalı, Çanakkale.

Sözüeroğlu, M. A. (2006). İlköğretim okulu müdürlerinin öğretim liderliği davranışlarının değerlendirilmesi. Yayınlanmamış Yüksek Lisans Tezi, Selçuk Üniversitesi Sosyal Bilimler Enstitüsü, Konya.

Summak,S., \& Şahin,Ç. (2013). Bilim ve sanat merkezi müdürlerinin ögrretimsel lider olarak ögretimsel uygulamalar hakkındaki görüşlerinin incelenmesi.Mersin Üniversitesi Ĕ̆itim Fakültesi Dergisi, 9(2), 1-14.

Şahin, A. E. (21-22 Nisan 2005). Eğitim hizmetlerinde kalite. AÇEV Okul Öncesi Eğitimi’nde Kalite Toplantısı Yayımlanmamış Raporu, İstanbul.

Şahin,Z.(2011).Ortaögretim okul müdürlerinin öğretimsel liderlik rolleri. Yüksek Lisans Tezi. İnönü Üniversitesi Eğitim Bilimleri Enstitüsü, Malatya.

Şişman, M. (2004). Öğretim liderliği. (1. Baskı). Ankara: Pegem Akademi. 
Şişman, M. (2012). Öğretim liderliği. (4. Baskı). Ankara: Pegem Akademi.

Tatlığlu,K \& Okyay,E.O.(2012).Özel eğitim okul müdürlerinin ve öğretmenlerin öğretim liderliği rolleri (Gaziantep örneği).International Periodical For The Languages, Literature and History of Turkish or Turkic, 7(2), 1045-1061.

Taymaz,H. (2003). Okul yönetimi. Ankara: Pegem Akademi.

T1kır, N. (2005). İlköğretim okulu müdürlerinin öğretimsel liderlik davranışlarıyla duygusal zekâları arasındaki ilişkinin incelenmesi (Gaziantep ili örneği), Yüksek Lisans Tezi, Gaziantep Üniversitesi Sosyal Bilimler Enstitüsü Eğitim Bilimleri Ana Bilim Dalı, Gaziantep.

Ural, O., \& Ramazan, O. (2007). Türkiye'de okul öncesi eğitimin dünü ve bugünü. In S. Özdemir, H. Bacanl1, \& Sözer,M. (Ed).Türkiye'de okul öncesi eğitim ve ilköğretim sistemi temel sorunlar ve çözüm önerileri, (ss.11-56). Ankara, Türk Eğitim Derneği.

Yıldırım, A., \& Şimşek, H. (2011). Sosyal bilimlerde nitel araştırma yöntemleri. Ankara: Seçkin Yayıncılık.

Yörük, S., \& Akdağ Akalın, G. (2010).İlköğretim okul müdürlerinin öğretimsel liderlik davranışlarının etkililiği ölçeğinin geliştirilmesi. Kuramsal Eğitimbilim, 3(1), 66-92. 